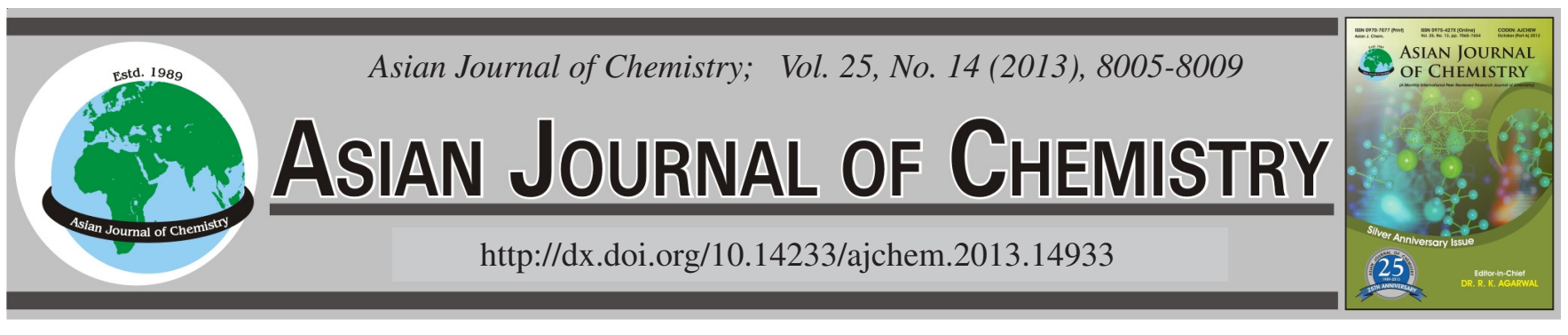

\title{
Recovery and Characterization of Struvite from Sediment and Sludge Resulting from the Process of Acid Whey Electrocoagulation
}

\author{
Francisco Prieto García, ${ }^{1, *}$ Judith Callejas Hernández ${ }^{1, *}$, Víctor E. Reyes Cruz', \\ Yolanda Marmolejo Santillán ${ }^{1}$, María A. Méndez Marzo ${ }^{2}$, Juan Hernández Ávilä and Fidel Pérez Moreno ${ }^{2}$
}

${ }^{1}$ Área Académica de Química, Universidad Autónoma del Estado de Hidalgo. Ciudad Universitaria. Carretera Pachuca-Tulancingo Km 4.5, Pachuca, Hidalgo, México

${ }^{2}$ Área Académica de Ciencias de la Tierra y Materiales, Universidad Autónoma del Estado de Hidalgo. Ciudad Universitaria. Carretera PachucaTulancingo Km 4.5, Pachuca, Hidalgo, México

*Corresponding author: E-mail: prietog@uaeh.edu.mx; judith_callejas@yahoo.com.mx; prietogmx@yahoo.com.mx

(Received: 8 December 2012;

Accepted: 29 July 2013)

AJC-13860

\begin{abstract}
The whey produced in the cheese making in the dairy industry, is a residual high organic and rich in phosphorus. Electrocoagulation is an electrochemical process in which from compounds from the dissolution of an anode, is grouped and deposited the dissolved and colloidal organic matter (removal of COD) existing in a residual liquid, allowing its separation from water using conventional techniques. The objective of the present work has been to retrieve the contents of phosphorus in whey from sludge and sediment that are obtained from an electrocoagulation using aluminum anode, $\mathrm{Ti} / \mathrm{RuO}_{2}$ cathode and applied voltage $3.67 \pm 0.02 \mathrm{~V}$ under conditions optimized previously. Phosphorus was recovered as fertilizer (precipitation in form of struvite, $\mathrm{MgNH}_{4} \mathrm{PO}_{4}$ ). Was removal the $86 \%$ of $\mathrm{COD}$, a recovery of $99.4 \%$ of the phosphorus present in whey and sediment and $87.4 \%$ was recovered from it in the form of struvite, which was identified and characterized by different instrumental analytical techniques.
\end{abstract}

Key Words: Whey, Electrocoagulation, Anode aluminum, Phosphorus removal, Struvite.

\section{INTRODUCTION}

The electrocoagulation process is similar to a typical chemical coagulation treatment but using electrical energy. Both processes are designed to destabilization of the colloids containing a residual water and differ in the mode of reagent addition: in conventional coagulation reagent is added as a salt and is generated from electrocoagulation of a metal ${ }^{1}$. Wastewater from the dairy industry is characterized by a high organic load given in chemical oxygen demand (COD) and fats. These pollutants generated a significant impact on the environment, especially water resources. Electrocoagulation is a process that has been developing in recent years and is presented as an alternative treatment for wastewater from this industry, offering multiple advantages to traditional technologies ${ }^{2}$.

The acid whey is especially rich in phosphorus, 10-12 times higher than the average may be present in the aqueous waste milk ${ }^{3}$, which makes it interesting as the recovery of value added products. Given the scarcity of this resource (phosphorus), recycling of this, present in the waste water, industrial waste in general and in the sludge resulting from the treatment processes, has become a real need and a challenge today.
According to Parsons et al. ${ }^{4} 83 \%$ of phosphorus is retained in the sludge or sediment sludge during water treatment. The recycling of phosphorus as struvite foresees a reduction in their generation, also avoids the extra cost for acquiring land for deposition and allows the development of products with a high value as agricultural fertilizer ${ }^{5-7}$. Thus, the recovery of phosphorus in waste streams is a basic process for achieving sustainable development.

\section{EXPERIMENTAL}

From an acid whey (pH $4.70 \pm 0.20)$ and under optimized conditions of the process of electrocoagulation (EC): time $8 \mathrm{~h}$, medium temperature $60{ }^{\circ} \mathrm{C}$, fluid flow, $75 \mathrm{~L} / \mathrm{h}$ and distance between electrodes, $1.0 \mathrm{~cm}$; worked with aluminum anode and $\mathrm{Ti} / \mathrm{RuO}_{2}$ cathode and applied voltage $3.67 \pm 0.02 \mathrm{~V}$ obtained a quantity of sludge and sediment formed by aluminum oxyhydroxides and organic matter cooprecipitada ${ }^{8}$.

Recovery of phosphorus: The recovery of phosphorus as fertilizer (struvite, $\mathrm{MgNH}_{4} \mathrm{PO}_{4}$ ), was made from phosphorus was removed with the whey treatment by electrocoagulation through the stripping of sludge obtained, previously dried at $60{ }^{\circ} \mathrm{C}$ in an oven and using the least amount of concentrated 
$\mathrm{HNO}_{3}$. Thus phosphate ions $\left(\mathrm{PO}_{4}{ }^{3-}\right)$, is made in the form of phosphoric acid $\left(\mathrm{H}_{3} \mathrm{PO}_{4}\right)$.

The principle of the method of determination of phosphorus is based on the reaction of phosphate ions $\left(\mathrm{PO}_{4}^{3-}\right)$ in solution with molybdic acid $\left(\mathrm{H}_{2} \mathrm{MoO}_{4}\right)$ [or ammonium molybdate $\left(\mathrm{NH}_{4}\right)_{2} \mathrm{MoO}_{4}$ ], forming phosphomolybdic, a yellow coloured complex which is measured photometrically ${ }^{9}$. Ascorbic acid may be added and the yellow coloured complex shape leucoreducida passes blue.

$$
\begin{array}{r}
\mathrm{PO}_{4}{ }^{3-}+3 \mathrm{NH}_{4}^{+}+12 \mathrm{MoO}_{4} \mathrm{H}_{2} \rightarrow \mathrm{PO}_{4}\left(\mathrm{NH}_{4}\right)_{3} 12 \mathrm{MoO}_{3} \\
+12 \mathrm{H}_{2} \mathrm{O}
\end{array}
$$

To avoid uncontrolled precipitation of $\mathrm{PO}_{4}{ }^{3-}$ ions present in the clear liquid resulting from the stripping of the sludge, $\mathrm{MgCl}_{2}{ }^{9}$ and concentrated $\mathrm{NH}_{4} \mathrm{OH}^{10}$ were added to achieve an alkaline $\mathrm{pH}$ ( 7 to 9 ). Also used (by some references consulted) aeration with $\mathrm{CO}_{2}{ }^{11,12}$ to assist the precipitation. Tests were conducted with and without aeration without significant variations in the results.

The $\mathrm{Mg}(\mathrm{OH})_{2}$ can present the drawback of not allowing control alone independently $\mathrm{pH}$ and $\mathrm{Mg} / \mathrm{P}$, two important parameters of the process, but rather promotes precipitation by increasing the concentration of magnesium which is consistent with that reported by other authors ${ }^{13}$. Failure to reach the stoichiometric ratio for the formation of struvite is usually added in the form of magnesium chloride.

The precipitation of struvite was controlled by the $\mathrm{pH}$ ( $\mathrm{pH}=9.0 \pm 0.2$ ), supersaturating with $\mathrm{Mg}^{2+}$ and the temperature, as is suggested in the literature ${ }^{14}$. This can occur when the concentrations of $\mathrm{Mg}^{2+}, \mathrm{NH}_{4}{ }^{+}$and $\mathrm{PO}_{4}{ }^{3-}$ ions exceed the solubility product (KPS). There is a great difference of opinion about reach this value, since the $\mathrm{pH}$ which provides maximum precipitation of struvite (eqn. 2) for minimum solubility values ranging from 8.0-10.7 ${ }^{15}$. Booker and colleagues ${ }^{16}$ considered that the optimum $\mathrm{pH}$ for this precipitation, ranging between 8.8 and 9.4; Strarful et al. ${ }^{10}$ define the $\mathrm{pH}$ at 8.5 .

$$
\mathrm{PO}_{4}{ }^{3-}+\mathrm{NH}_{4}{ }^{+}+\mathrm{Mg}^{2+} \rightarrow \mathrm{MgNH}_{4} \mathrm{PO}_{4} \downarrow
$$

Because it is highly soluble $\mathrm{NH}_{4} \mathrm{H}_{2} \mathrm{PO}_{4}$ and $\mathrm{MgO}$ is hardly soluble in water is a solution rich in ammonium and phosphate ions but low concentration of magnesium ions. According Winbow $(1988)^{17}$, reaches supersaturation and schertelita form $\left[\mathrm{Mg}\left(\mathrm{NH}_{4}\right)_{2}\left(\mathrm{HPO}_{4}\right)_{2} \cdot 4 \mathrm{H}_{2} \mathrm{O}\right]$ in the first minutes of hydration:

$$
\mathrm{MgO}+2 \mathrm{NH}_{4} \mathrm{H}_{2} \mathrm{PO}_{4}+3 \mathrm{H}_{2} \mathrm{O} \rightarrow \mathrm{Mg}\left(\mathrm{NH}_{4}\right)_{2}\left(\mathrm{HPO}_{4}\right)_{2} \cdot 4 \mathrm{H}_{2} \mathrm{O} \text { (3) }
$$

Then, with decreasing concentration of ammonium and phosphate ions, conversion occurs in the schertelita, provided that sufficient quantity of water (eqn. 4). It is noted that the relationship $\mathrm{Mg}^{2+} / \mathrm{PO}_{4}{ }^{3-}$ or $\mathrm{Mg}^{2+} / \mathrm{NH}_{4}{ }^{+}$in the schertelita is 0.5 , whereas the ratio is 1 in the struvite.

$$
\begin{array}{cc}
\mathrm{Mg}\left(\mathrm{NH}_{4}\right)_{2}\left(\mathrm{HPO}_{4}\right)_{2} \cdot 4 \mathrm{H}_{2} \mathrm{O}+\mathrm{MgO}+\underset{ }{\text { Schertelite }} & 7 \mathrm{H}_{2} \mathrm{O} \rightarrow \\
2 \mathrm{NH}_{4} \mathrm{MgPO}_{4} \cdot 6 \mathrm{H}_{2} \mathrm{O} & \text { Struvite }
\end{array}
$$

The sediments and slurries were separated from the resulting liquid, dried at $45-50{ }^{\circ} \mathrm{C}$ in an oven for $96 \mathrm{~h}$ and dissolved in the least amount of concentrated nitric acid, once in the form of $\mathrm{PO}_{4}{ }^{3-}$ ions, was added to the clear liquid solution $\mathrm{MgCl}_{2} \cdot 6 \mathrm{H}_{2} \mathrm{O} 2.32 \mathrm{~g} \mathrm{~L}^{-1}$ in order to achieve the $1: 1 \mathrm{v} / \mathrm{v} \mathrm{P}: \mathrm{Mg}$, concentrated $\mathrm{NH}_{4} \mathrm{OH}$ was added drop wise immediately to reach an alkaline $\mathrm{pH}(\mathrm{pH}=9.0 \pm 0.2)$. This process is known as MAP (magnesium ammonium phosphate) or struvite ${ }^{4}$. Moreover struvite was synthesized from the stoichiometric $\mathrm{P}$ : $\mathrm{Mg}$ and from $\mathrm{Na}_{2} \mathrm{HPO}_{4} \cdot 12 \mathrm{H}_{2} \mathrm{O}, \mathrm{MgCl}_{2} \cdot 6 \mathrm{H}_{2} \mathrm{O}$ and $\mathrm{NH}_{4} \mathrm{OH}^{18}$. Likewise the precipitate was obtained which was filtered, washed, dried under the same conditions and low wash three times with alkaline solution of $\mathrm{NH}_{4} \mathrm{OH}^{15}$.

Characterization of struvite: An evaluation and characterization of struvite obtained by both ways using scanning electron microscopy, X-ray diffraction, size and distribution of particles struvite, infrared spectroscopy, differential thermal analysis and Raman spectroscopy. SEM was obtained by an electron microscope JEOL JSM-820 at $20 \mathrm{kV}$. XRD was used for diffractometer PHILIPS, model PW-1710-BASED with $\mathrm{CuK}_{\alpha}$ radiation source, $\lambda=0.15406 \mathrm{~nm}$, filter nickel, aluminum sample holder and current generator voltage of $40 \mathrm{KV}$ and 30 $\mathrm{mA}$, respectively, sweep angles $(2 \theta)$ of $5-70^{\circ}$. The distribution and particle size were measured by a laser analyzer signature Beckman Coulter, LS 13-320. FTIR characterization was performed on Perkin Elmer model IRDM in $\mathrm{KBr}$ pellet to minimize the effect of water present.

The characterization by thermal analysis was performed on a Mettler DSC-50, in crucibles open aluminum in air atmosphere with a flow of $20 \mathrm{~mL} / \mathrm{min}$, maximum heating temperature of $500{ }^{\circ} \mathrm{C}$ and heating rate of $10{ }^{\circ} \mathrm{C} \mathrm{min}{ }^{-1}$. For each of the measurements was taken next sample weighing 10 $\mathrm{mg}$. The results are reported graphically indicating in each case the initial temperature, maximum and end of each exothermic or endothermic transformation and the amount of heat involved in each transformation. With this technique, confirming the variation of each processing areas or variations of the quantities of heat in the sample.

Raman spectra were obtained with a Raman spectrometer GX-FTIR of Perkin Elmer equipped with a Nd:YAG laser $(1064 \mathrm{~nm})$ and an InGaAs detector. Raman spectra were obtained with $40-300 \mathrm{~mW}$ laser power between $3500-100 \mathrm{~cm}^{-1}$.

\section{RESULTS AND DISCUSSION}

When performing whey electrocoagulation under optimized conditions, the $\mathrm{pH}$ increased from 4.81-6.53; COD removal was achieved in 86 and $99.4 \%$ recover the initial phosphorus present in the whey $\left(2.36 \mathrm{~g} \mathrm{~L}^{-1}\right)$ as phosphate and finally $87.3 \%$ was recovered as struvite $\left(\mathrm{MgNH}_{4} \mathrm{PO}_{4}\right)$ precipitated. These results correspond almost exactly with those reported by Bouropoulos and Koutsoukos ${ }^{14}$, Battistoni et al..$^{11}$, Strarful et al. ${ }^{10}$ and Pastor et al. ${ }^{18}$ when they conducted studies to recover phosphorus in wastewater. The pure struvite containing $9.9 \% \mathrm{Mg}, 5.7 \% \mathrm{~N}$ and $12.6 \%$ of $\mathrm{P}$, which makes the fertilizer NPK type 5.7-29-0 formula expressed as $\mathrm{N}_{-} \mathrm{P}_{2} \mathrm{O}_{5^{-}}$ $\mathrm{K}_{2} \mathrm{O}$ improved with addition of $\mathrm{Mg}(9.9 \%)$.

It was observed the formation of an abundant white precipitate was obtained by two ways. Both products were then characterized. Fig. 1 shows a photograph of the product obtained from sludge process digestados electrocoagulation. The $\mathrm{pH}$ was found to have a strong influence on the precipitation of struvite and aeration of the medium with $\mathrm{CO}_{2}$ only made were obtained at $\mathrm{pH}$ values less than 9.0, i.e., reaching down to 8.7. When this happened there was a decrease in the yield of the precipitate formed $(81.34 \%)$. 


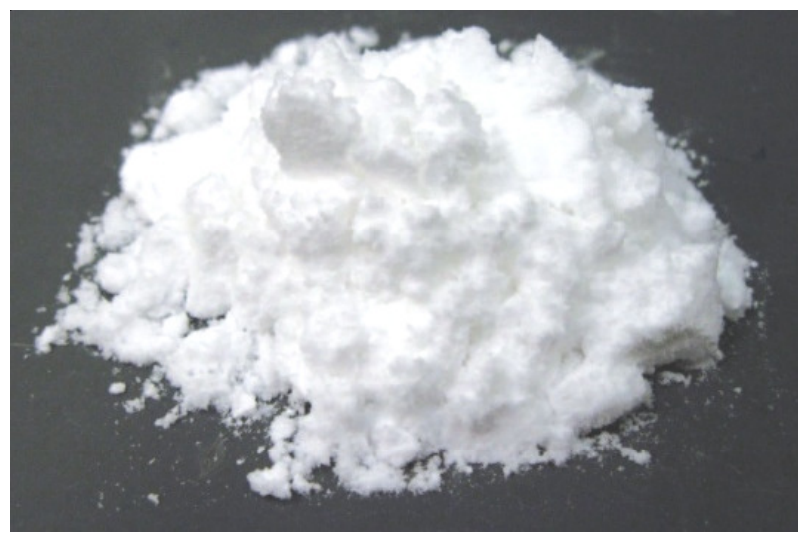

Fig. 1. Photograph of $\mathrm{MgNH}_{4} \mathrm{PO}_{4} \cdot 6 \mathrm{H}_{2} \mathrm{O}$ precipitate (struvite) was obtained from the stripping of sediment and sludge from the process under conditions optimized electrocoagulation

Assess performance was tested at different $\mathrm{pH}$ struvite which were varied between 8.0 and 9.5 with addition of concentrated $\mathrm{NH}_{4} \mathrm{OH}$ (Fig. 2).

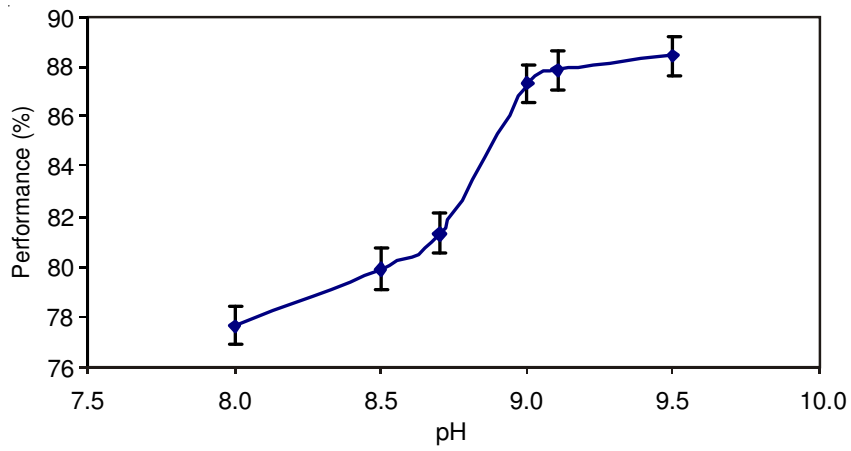

Fig. 2. Performance (\%) of $\mathrm{MgNH}_{4} \mathrm{PO}_{4} \cdot 6 \mathrm{H}_{2} \mathrm{O}$ precipitate (struvite) obtained at different $\mathrm{pH}$

These results correspond to those reported by Booker et al. ${ }^{16}$ who believe that the optimum $\mathrm{pH}$ for this precipitation ranges between 8.8 and 9.4 (Fig. 2). It is found that the solubility of struvite decreases with increasing $\mathrm{pH}$ and at $\mathrm{pH} 8.0$ under practically not reached KPS or struvite, rapidly dissolves at $\mathrm{pH}$ below $5.5^{15}$.

The crystalline compound struvite was subjected to characterization and identification by XRD. Struvite is thermally unstable at temperatures above $50{ }^{\circ} \mathrm{C}$. It may lose all or part of the ammonium molecules and/or water depending on the temperature reached and the time of exposure to such temperatures. When five loses its crystallization water molecules, form the monohydrate struvite $\left(\mathrm{MgNH}_{4} \mathrm{PO}_{4} \cdot \mathrm{H}_{2} \mathrm{O}\right)$ which is called dittmarite $^{19}$. If the sixth loses water molecule becomes anhydrous. Fig. 3 shows the XRD spectrum of struvite digestados sludge obtained, which is compared with the pattern spectrum of pure struvite synthesized (Fig. 4) and shows the same patterns and signals.

When analyzing the data presented in PDF 015-0762 ${ }^{13}$ could be observed (Table-1) displayed the nine (9) strongest signals ( $>25 \%$ relative, marked in the table), for both diffractograms almost total correspondence exists between them.

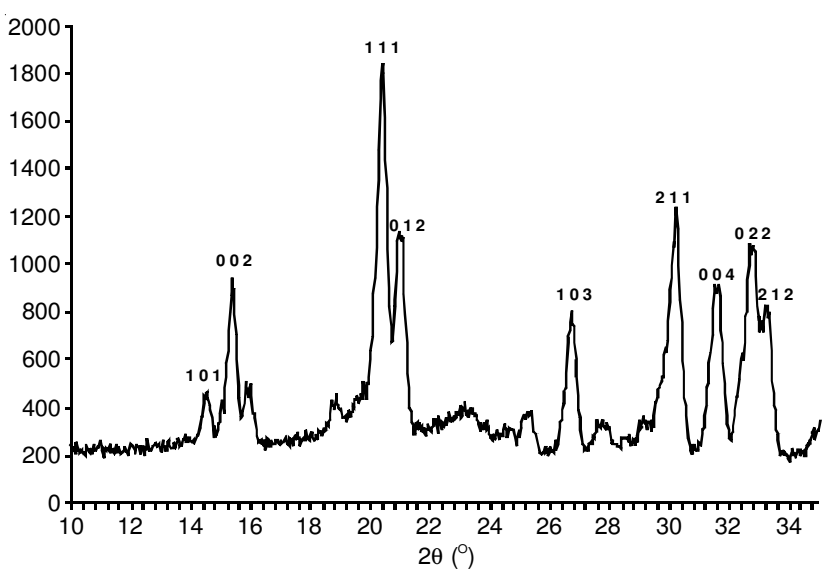

Fig. 3. Diffractogram obtained struvite

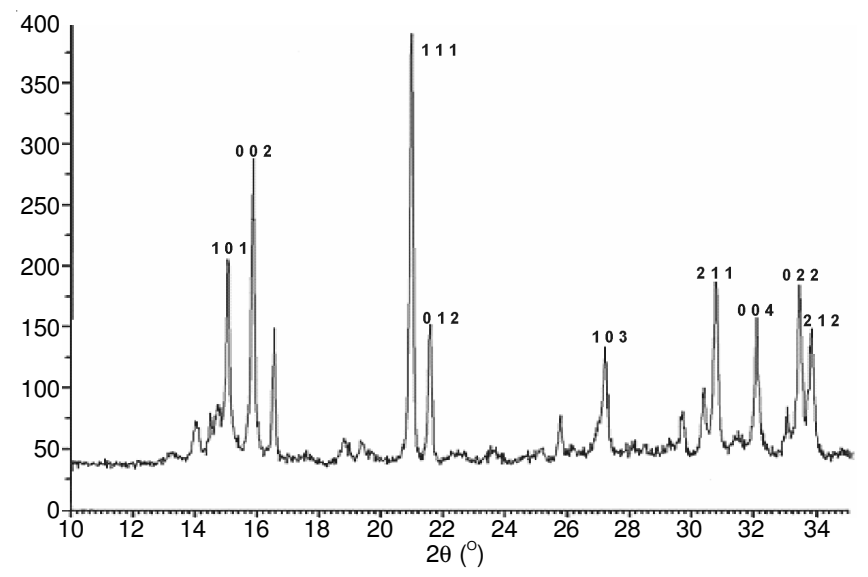

Fig. 4. Diffractogram of synthesized pure struvite

TABLE-1

PDF 015-0762 (TAKEN IN PART FROM DOWNS et al. ${ }^{13}$ )

\begin{tabular}{cccccc}
\hline $2 \theta$ & Intensity $(\%)$ & d-Interplanar distance $(\AA)$ & $\mathrm{h}$ & $\mathrm{k}$ & $\mathrm{l}$ \\
\hline 15.00 & 35.80 & 5.9002 & 1 & 0 & 1 \\
15.80 & 56.84 & 5.6027 & 0 & 0 & 2 \\
16.46 & 24.10 & 5.3784 & 0 & 1 & 1 \\
20.87 & 100.00 & 4.2512 & 1 & 1 & 1 \\
21.46 & 34.33 & 4.1358 & 0 & 1 & 2 \\
27.08 & 25.91 & 3.2891 & 1 & 0 & 3 \\
29.55 & 10.67 & 3.0199 & 2 & 1 & 0 \\
30.63 & 30.18 & 2.9159 & 2 & 1 & 1 \\
31.92 & 31.42 & 2.8014 & 0 & 0 & 4 \\
32.90 & 8.22 & 2.7202 & 1 & 2 & 1 \\
33.29 & 44.32 & 2.6892 & 0 & 2 & 2 \\
33.68 & 38.76 & 2.6583 & 2 & 1 & 2 \\
35.78 & 6.56 & 2.5075 & 1 & 2 & 2 \\
38.29 & 10.98 & 2.3484 & 2 & 1 & 3 \\
44.05 & 10.43 & 2.0538 & 2 & 1 & 4 \\
50.68 & 10.63 & 1.7997 & 2 & 1 & 5 \\
\hline
\end{tabular}

At $20.87^{\circ}$ appears strongest signal (which is taken as $100 \%$ ) in both diffractograms, then the signal appears with a $15.80^{\circ} 56.8 \%$ intensity. Other major signals appearing between $38.7-25.9 \%$ of intensities ${ }^{13}$. These results corroborate the formation of struvite phosphate precipitation digestate sludge and sediment of the electrocoagulation derived from whey.

In a recent work ${ }^{18}$ studied the precipitation and recovery of phosphorus in wastewater as struvite $\left(\mathrm{MgNH}_{4} \mathrm{PO}_{4} \cdot 6 \mathrm{H}_{2} \mathrm{O}\right)$ was reported obtained average particle size ranging between 10 and $100 \mu \mathrm{m}$ general $(60 \mu \mathrm{m})$ and having read the $10 \%$ of 
the sample had particles of size $24 \mu \mathrm{m}, 50 \%$ of sample read, a particle size of $42 \mu \mathrm{m}$ and $90 \%$ of a size readings of $79 \mu \mathrm{m}$.

In the present study and reading equipment similar to the work reported above, was obtained particle size distribution and struvite shown in Fig. 5. It is seen that the average size was $45.13 \mu \mathrm{m}$, similar to that reported by Pastor and colleagues ${ }^{18}$. This may be given by the same values equal percentile levels, which were $22.41 \mu \mathrm{m}$ (for $10 \%$ of reading), $37.41 \mu \mathrm{m}$ (for $50 \%$ read) and $61.20 \mu \mathrm{m}$ (when it reached $90 \%$ of sample read), that is $0.7-0.8$ times lower. Importantly, the sizes of the crystals were very uniform.

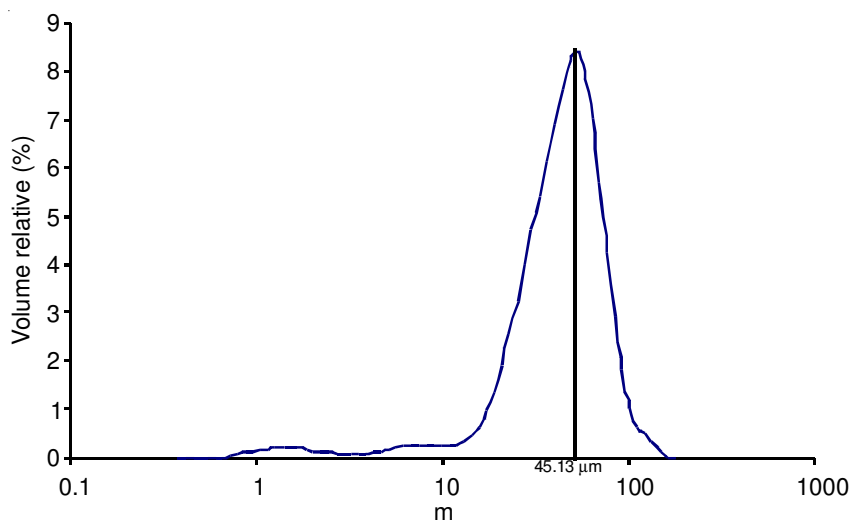

Fig. 5. Particle size and distribution average in struvite

FTIR spectroscopy of struvite crystals obtained similarly to characterize the product (Fig. 6) identifying the signals appearing at $3523.7,3483.5,3385.1$ and $3276.8 \mathrm{~cm}^{-1}$ which are associated with the stretching vibration bands of bond $-\mathrm{OH}$ and $-\mathrm{NH}$ water molecules and the ion $\mathrm{NH}_{4}{ }^{+}$, respectively ${ }^{19-22}$. In turn, the spectrum identify the presence of water of crystallization.

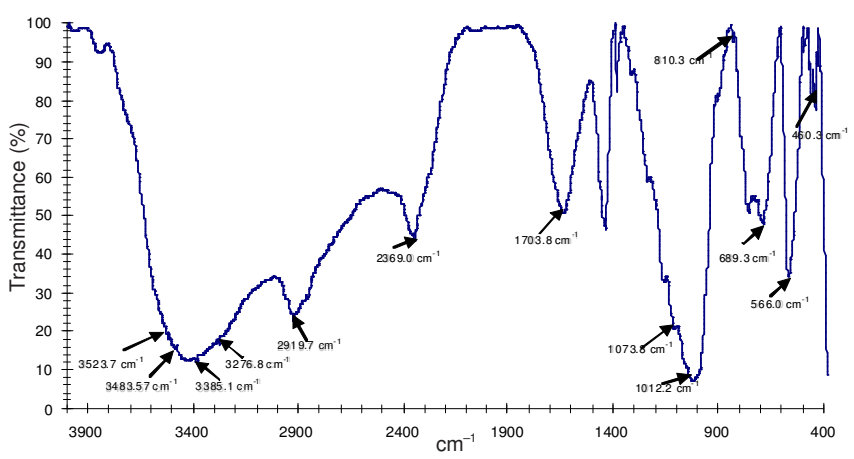

Fig. 6. FTIR spectrum of the obtained struvite

The band appearing at $2919.7 \mathrm{~cm}^{-1}$ is attributable to the ammonium ion and the band at $1703.9 \mathrm{~cm}^{-1}$ is due to the bending vibration of - $\mathrm{NH}$ bond. Moreover, the signals of the bands found at 2369.0, 1073.8 and $1012.2 \mathrm{~cm}^{-1}$ may be attributed to the presence of $\mathrm{PO}_{4}^{3-}$ ions have been reported by Chauhan et $a l^{23}$ and Kanchana et al. ${ }^{24}$. Also the bands that appear to 810.3 and $689.3 \mathrm{~cm}^{-1}$ are justified and are due to rotations of the $-\mathrm{NH}$ bonds, also the band $566 \mathrm{~cm}^{-1}$ is associated with asymmetric stretching vibration and the band $\mathrm{P}-\mathrm{O}-\mathrm{P}$ $460.3 \mathrm{~cm}^{-1}$ may be attributed to metal-oxygen vibration, namely $\mathrm{Mg}-\mathrm{O}^{25,26}$.
Raman spectroscopy confirmed the presence of the symmetric stretching vibration unit to $\mathrm{HPO}_{4}{ }^{2-} 945 \mathrm{~cm}^{-1}$, the most intense struvite have been reported by the vibration at 561.1 $\mathrm{cm}^{-1}$, the second largest ${ }^{27}$. Raman spectra are characterized by multiple antisymmetrical vibration bands stretching and bending modes indicating strong distortion of the units $\mathrm{HPO}_{4}{ }^{2-}$ and $\mathrm{PO}_{4}{ }^{3-}$. Other less intense bands appear $3382 \mathrm{~cm}^{-1}$ and are attributed to the vibrations of the type HO-P-O and vibration at 3020 and $2874 \mathrm{~cm}^{-1}$ are assigned to the presence of $\mathrm{NH}_{4}^{+}$ groups. Fig. 7 shows the Raman spectrum.

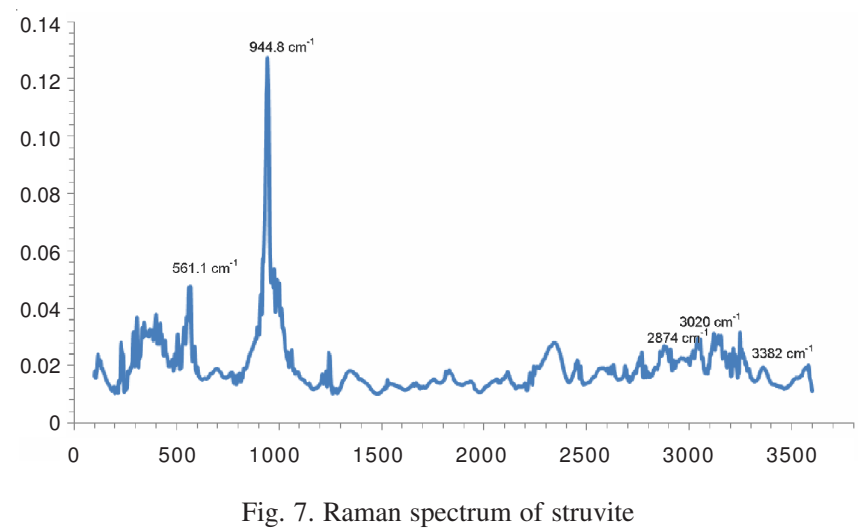

The photomicrographs shown in Fig. 8 allows to observe the morphology of struvite crystals. Struvite belongs to the orthorhombic crystal system, pyramidal class and unit cell parameters are: $\mathrm{a}=6.94 \AA, \mathrm{b}=11.2 \AA, \mathrm{c}=6.13 \AA^{24-26}$ at a density of $1,706 \mathrm{~g} \mathrm{~cm}^{-3}$ at $25^{\circ} \mathrm{C}$.
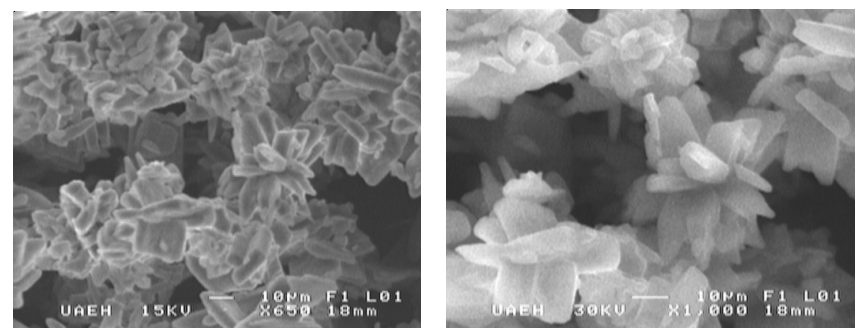

Fig. 8. Micrograph of struvite crystals obtained at $\mathrm{pH}=9.0 \pm 0.2$

Particle sizes can be estimated and in turn verify that appear as small as particles larger than 10ìm as shown in Fig. 6, to sizes as large as $c a .50 \mu \mathrm{m}$ as noted Pastor et al. ${ }^{18}$. This morphology also corresponds with those reported by previous workers $^{28,29}$.

The DES spectrum of struvite (Fig. 9) shows the presence of phosphorus, nitrogen, magnesium and oxygen composition. It also displayed signs that identify as potassium and may have precipitated as impurity occluded in the solid. This is in line with that reported by Yeon-Koo and Jin-Soo ${ }^{30}$ who reported the presence of potassium $\mathrm{K}_{\mathrm{a}}$ lines.

Thermal analyzes (TGA) of struvite showed that struvite is thermally unstable ${ }^{31}$ at temperatures above $50{ }^{\circ} \mathrm{C}$. It can be seen that the thermal decomposition starts at about that temperature (Fig. 10). Thereafter, begin to lose all or part of the molecules of water and ammonium, depending on the temperature reached. 


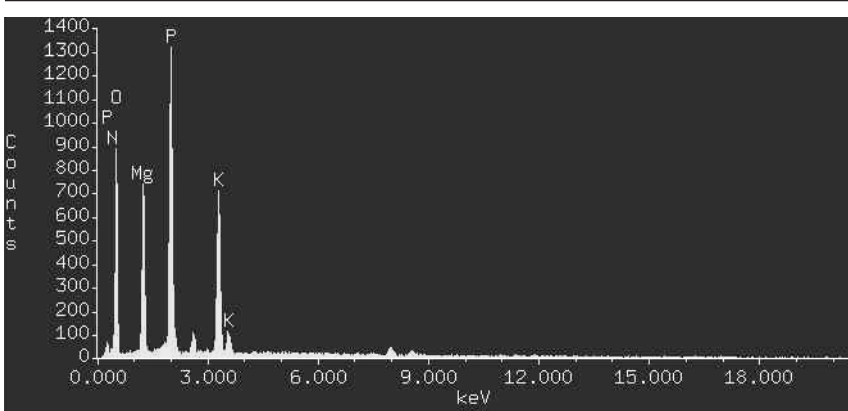

Fig. 9. EDS spectrum of struvite

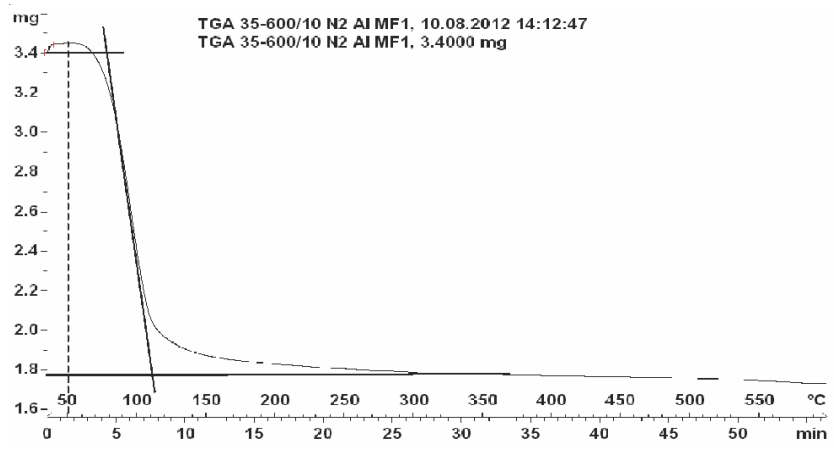

Fig. 10. Thermal gravimetric analysis of struvite

Thereafter, begin to lose all or part of the molecules of water and ammonium, depending on the temperature reached. It can be understood that up to $110^{\circ} \mathrm{C}$, loses five molecules of water of crystallization is formed struvite monohydrate $\left(\mathrm{MgNH}_{4} \mathrm{PO}_{4} \cdot \mathrm{H}_{2} \mathrm{O}\right)$ known as Dittmarite and attributable to the loss of $37 \% \mathrm{~m} / \mathrm{m}$ of the initial mass. Between $110-200{ }^{\circ} \mathrm{C}$, lose another molecule of water and was attributed to a loss of $7 \% \mathrm{~m} / \mathrm{m}$ forming $\mathrm{NH}_{4} \mathrm{MgPO}_{4}$. The detachment of one molecule of ammonia occurs gradually around $200-300{ }^{\circ} \mathrm{C}$ attributing to $7 \% \mathrm{~m} / \mathrm{m}$ of weight loss which gives rise to the formation of $\mathrm{MgHPO}_{4}$. These results correspond to those reported by other authors ${ }^{17,32-35}$. The total weight loss is $51 \%$ $\mathrm{m} / \mathrm{m}$ which corresponds to $49 \% \mathrm{~m} / \mathrm{m}$ of $\mathrm{MgHPO}_{4}$.

\section{Conclusion}

The process of electrocoagulation is effective and allows a total COD removal of $86 \%$. From sludge and sediments which are formed as a result of electrocoagulation is achieved recovering $99.4 \%$ of the phosphorus presents in the initial whey as phosphate and organic fillers products and sedimented aluminum oxyhydroxide (by redissolution of nitric acid sludge and subsequent precipitation of phosphate). The phosphorus was recovered in $87.4 \%$ of this form of struvite $\left(\mathrm{NH}_{4} \mathrm{MgPO}_{4} \cdot 6 \mathrm{H}_{2} \mathrm{O}\right)$. The $\mathrm{pH}$ range for effective precipitation of struvite was corroborated in $9.00 \pm 0.20$. The struvite formed was identified and characterized by XRD, FTIR, SEM, DTA and Raman spectra.

\section{REFERENCES}

1. M. Khemis, G. Tanguy, J.P. Leclerc, G. Valentin and F. Lapicque, Chem. Eng. Sci., 61, 3602 (2006).

2. A. Arango, L.F. Garcés, S. Molina and J.S. Piedrahita, Producción Limpia, 3, 9 (2008).
3. A. Abaigar, El lactosuero en la alimentacion del ganado porcino, ITG Ganadero, pp. 13-17 (2009); ISSN- 948-5656.

4. S.A. Parsons, F. Wall, J. Doyle, K. Oldring and J. Churchley, Environ. Technol., 22, 1279 (2001).

5. W. Römer, J. Plant Nutr. Soil Sci., 169, 832 (2001).

6. L. Shu, P. Schneider, V.Y. Jegatheesan and J. Johnson, Bioresour. Technol., 97, 2211 (2006).

7. N. Marti, L. Pastor, A. Bouzas, J.Y. Ferrer and A. Seco, Water Res., 44, 2371 (2010).

8. J. Callejas, F. Prieto, V. E. Reyes, Y. Marmolejo and E. Bustos, Rev. Tecnol. Quím., 32, (2012).

9. APHA, AWWA, WPCF, Standard Methods for the Examination of Water and Wastewater, American Public Health Association: Washington, DC, edn. 17 (1989).

10. I. Strarful, M.D. Scrimshaw and J.N. Lester, Water Res., 35, 4191 (2001).

11. P. Battistoni, P. Pavan, M. Prisciandaro and F. Cecchi, Water Res., 35, 3033 (2001).

12. Y. Jaffer, T.A. Clark, P. Pearce and S.A. Parsons, Water Res., 35, 2101 (2001).

13. J.D. Doyle and S.A. Parsons, Water Res., 36, 3925 (2002).

14. N. Bouropoulos and P.G. Koutsoukos. Crystal Growth, 213, 381 (2000).

15. L. Pastor, Tesis Doctoral, Departamento de Ingeniería Hidraúlica y Medio Ambiente. Universidad Politécnica de Valencia, España (2008).

16. N.A. Booker, A.J. Priestley and A.J. Fraser, Environ. Technol., 20, 777 (1999).

17. H.D. Winbow, PhD Thesis, School of Materials, Faculty of Engineering, University of Sheffield, UK (1988).

18. L. Pastor, D. Mangin, R. Barat and R. Seco, Bioresour. Technol., 99, 6285 (2008).

19. Q. Wu and P.L. Bishop, J. Environ. Eng. Sci., 3, 21 (2004).

20. X.Z. Li and Q.L. Zhao, Environ. Int., 45, 961 (2011).

21. V. Stefov, B. Soptrajanov, F. Spirovski, I. Kuzmanovski, H.D. Lutz and B. Engelen, J. Mol. Struct., 689, 1 (2004).

22. V. Stefov, B. Soptrajanov, I. Kuzmanovski, H. D. Lutz and B. Engelen, J. Mol. Struct., 752, 60 (2005).

23. S. Chauhan, R.S. Khandewal, K.V. Prahbu, S.K. Sinha and R. KhannaChopra, J. Agron. Crop Sci., 191, 88 (2005).

24. G. Kanchana, P. Sundaramoorthi and J.P. Jeyanthi, J. Min. Mater. Character. Eng., 8, 161 (2009).

25. J. Kontrec, V.I. Babi and B. Ljerka, Coll. Antropol., 29, 289 (2005).

26. JCPDS, International Centre for Diffraction Data, Ammonium Magnesium Phosphate Hydrate, (Standard \#15-0762), A Computer Database (1996).

27. S.D.W. Frost, T. Wrin, D.M. Smith, S.L. Kosakovsky, Y. Liu, E. Paxinos, C. Chappey, J. Galovich, J. Beauchaine, C.J. Petropoulos, S.J. Little and D.D. Richman, Proc. Nat. Acad. Sci., 102, 18514 (2005).

28. G. Kurtulus and A.C. Tas, Mater. Lett., 65, 2883 (2011).

29. H.E. Swanson, M. Morris and E.H. Evans, Standard X-Ray Diffraction Powder Patterns, National Bureau of Standards Monograph, 25 Section 3, 41 (1994).

30. Y.-K. Jeong and J.-S. Kim, Bioresour. Technol., 79, 129 (2001).

31. M.S. Massey, J.A. Ippolito, J.G. Davis and R.E. Sheffield, Bioresour. Technol., 101, 877 (2010).

32. S. Graeser, W. Postl, H. Bojar, P. Berlepsch, T. Armbruster, T. Raber, K. Ettinger and F. Walter, Eur. J. Mineral., 20, 629 (2008).

33. H.W. Li, Z.P. Ye, Y. Lin and F.Y. Wang, Water Sci. Technol., 65, 2091 (2012).

34. N.E. Hipedinger, A.N. Scian and E.F. Aglietti, Actas Congreso binacional SAM-CONAMET, Jornadas MEMAT, in CD (2005).

35. N.E. Hipedinger, Tesis presentada para el grado de Doctor en Ingeniería. Área Departamental Construcciones. Facultad de Ingeniería, Universidad Nacional de La Plata. Argentina (2007). 